\author{
Gunta Ozolina', Signe Tomsone ${ }^{2}$ \\ 1 Department of Doctoral studies, Rīga Stradinš University, Latvia \\ 2 Faculty of Rehabilitation, Riga Stradinš University, Latvia
}

Introduction. This study is the first part of the larger study with the aim to assess the quality of life and mortality in elderly patients one year after hip fracture. The baseline data will set the ground for the forthcoming follow up studies in 6 and 12 months after the hip fracture. In Latvia, the quality of life has not been evaluated among the elderly patients after a hip fracture and there is also no information how it changes over the time.

Purpose. The aim of this study is to explore the quality of life and other characteristics of elderly patients (> 65 years) after hip fracture.

Methods. Participants were patients with a traumatic hip fracture, older than 65 years. Data were collected at the hospital stage. The general quality of life was assessed by World Health Organization Quality of Life Questionnaire (WHOQoL- BREF) and health-related quality of life was assessed by Hip dysfunction and Osteoarthritis Outcome Score (HOOS). For both assessments 100 indicate that there are no problems and 0 indicate extreme problems. Spearmens corelations analysis was performed to asses the relation between subscales of WHOQoL-BREF and HOOS and QoL assesment and satisfaction with state of health.

Results. 40 patients with hip fracture at the hospital stage participated in the study. Mean age was 80.08 years (min 65 years and max 93 years). 30 participants were women and 10 participants were men.

HOOS scores were (mean scores, (SD)): for pain subscale - 88.4 (18.1), for symptom subscale - 87.6 (15.3), ADL subscale -75.0 (20.2), for sport and recreation -57.8 (28.4), for hip related QOL subscale - 92.1 (17.0).

WHOQOL-Bref score were (mean score, (SD)) for physical health subscale - 64,73 $(18,06)$, for psychological health subscale - 58,02 $(15,83)$, for social relationships subscale - 70,0 (15,42), for environment subscale $-72,97(12,20)$

Quality of life assesment were (mean score, (SD))- 71,25 (SD19,24). Satisfation with state of health were (mean score, (SD))- 56,25 (SD22,47).

The statistically significant moderate correlation was between Quality of life assessment and all WHOQOL-BREF subscales. The statistically significant weak correlation was between Quality of life assessment and HOOS subscales pain, symptoms, ADL and subscale recreation /sports. The statistically significant weak correlation was between HOOS Hip related Quality of life subscale and WHOQOLBREF assessment satisfation with state of health.

\section{Results for HOOS}

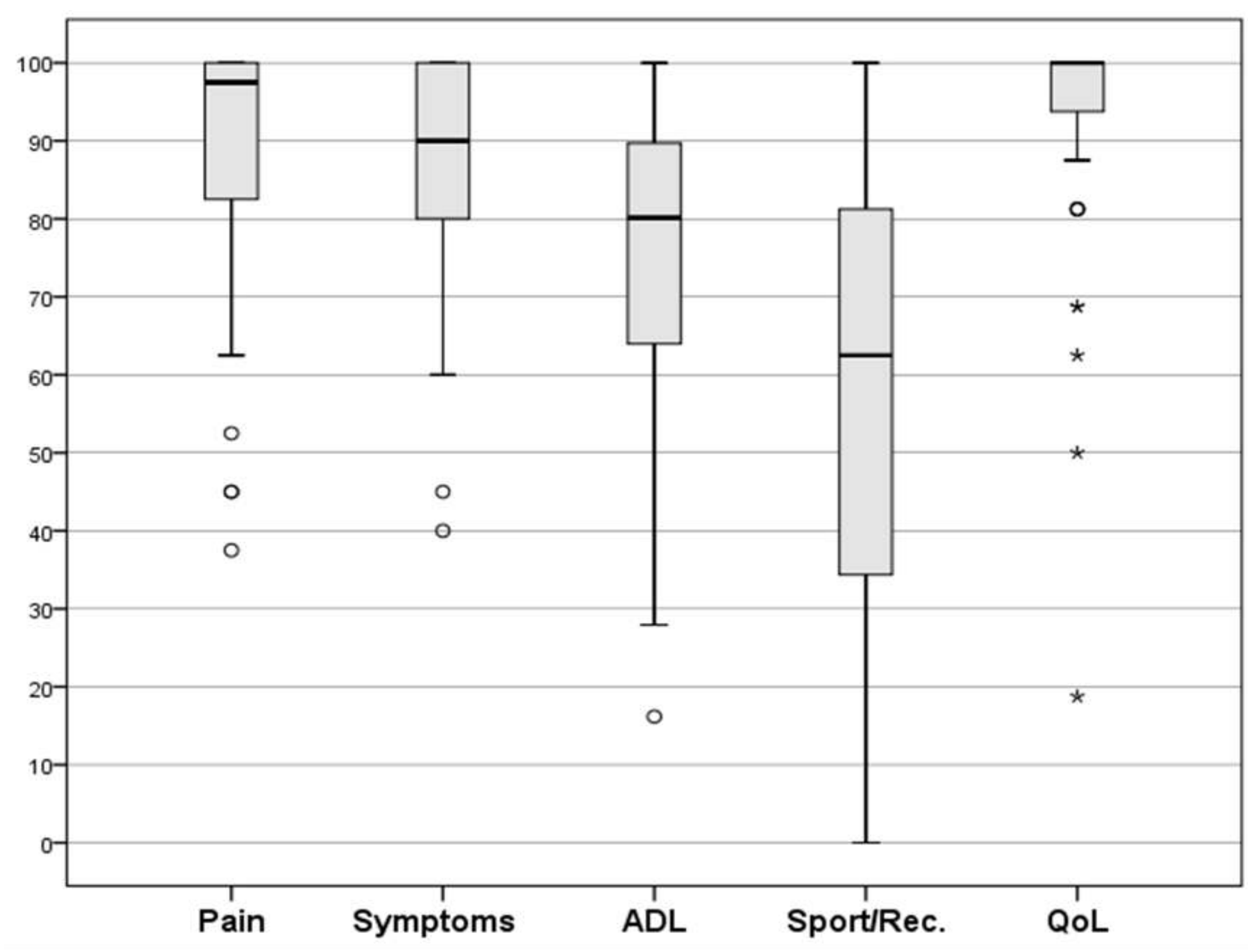

Results for WHOQoL- BREF

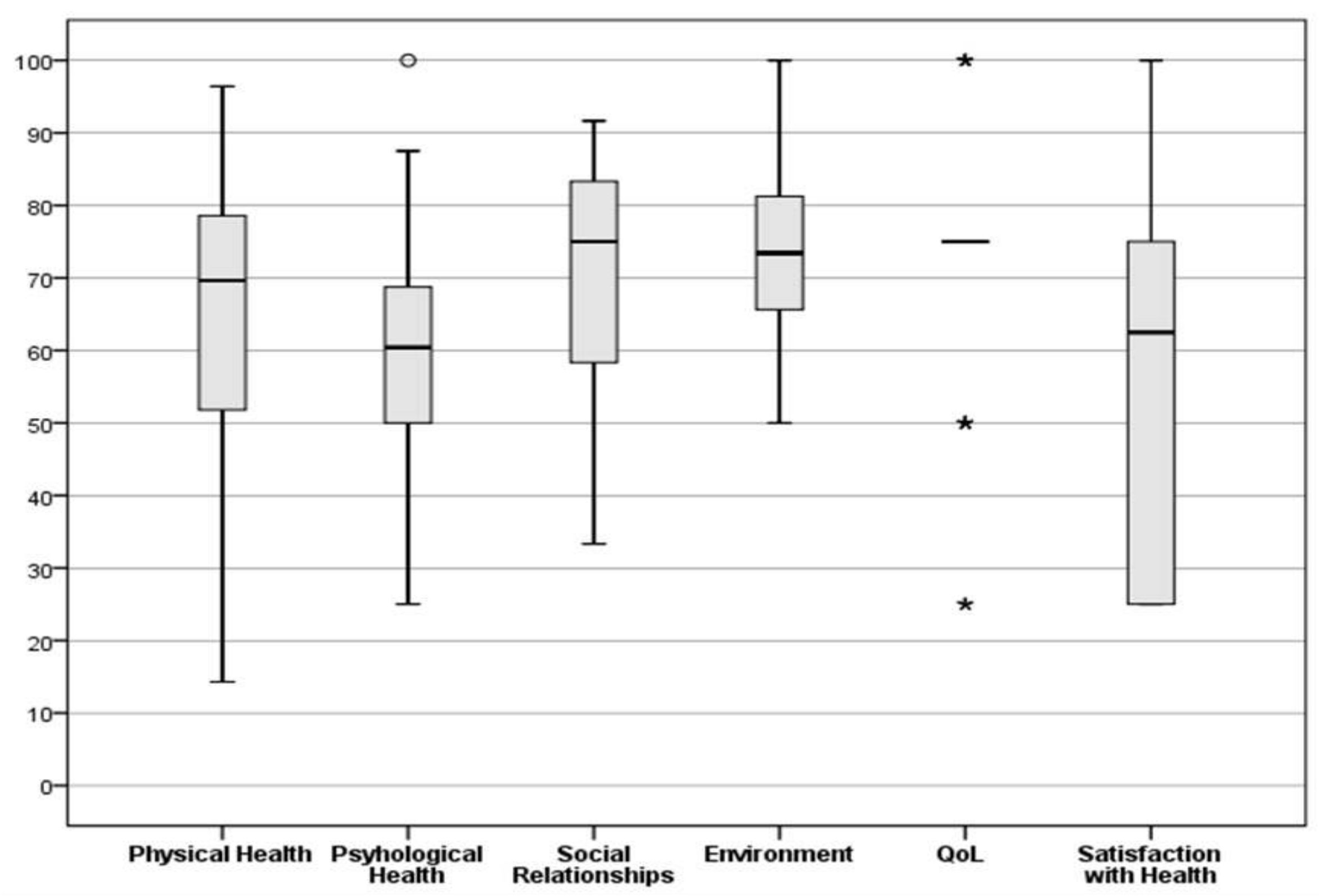

Correlations between subscales of WHOQOL-BREF and HOOS and QoL assesment and satisfaction with state of health

\begin{tabular}{|c|c|c|c|c|c|c|c|c|c|c|c|}
\hline & $\begin{array}{l}\text { Physi } \\
\text { cal } \\
\text { Health }\end{array}$ & $\begin{array}{c}\text { Psych } \\
\text { o } \\
\text { logica }\end{array}$ & $\begin{array}{c}\text { Social } \\
\text { relatio } \\
\text { nship } \\
\text { s }\end{array}$ & $\begin{array}{c}\text { Envi } \\
\text { ron } \\
\text { ment }\end{array}$ & $\begin{array}{l}\text { Qualit } \\
\text { yof } \\
\text { life } \\
\text { asses } \\
\text { sment }\end{array}$ & $\begin{array}{c}\text { Satisfat } \\
\text { ion with } \\
\text { state of } \\
\text { health }\end{array}$ & $\begin{array}{c}\text { Pai } \\
\text { n }\end{array}$ & $\begin{array}{c}\text { Sym } \\
\text { p } \\
\text { toms }\end{array}$ & $\begin{array}{c}\text { Functi } \\
\text { on, } \\
\text { daily } \\
\text { living }\end{array}$ & $\begin{array}{c}\text { Recr } \\
\text { eatio } \\
\text { nal } \\
\text { activi } \\
\text { ties }\end{array}$ & $\begin{array}{c}\text { Hip } \\
\text { relat } \\
\text { ed } \\
\text { Qual } \\
\text { ity } \\
\text { of } \\
\text { life }\end{array}$ \\
\hline $\begin{array}{c}\text { Quality of } \\
\text { life } \\
\text { assessment }\end{array}$ & 0,528 & 0,492 & 0,396 & 0,414 & & 0,388 & 0,399 & 0,342 & 0,389 & 0,242 & 0,306 \\
\hline $\mathbf{p}$ & 0,000 & 0,001 & 0,011 & 0,008 & & 0,013 & 0,011 & 0,031 & 0,013 & 0,133 & 0,055 \\
\hline $\begin{array}{c}\text { Satisfaction } \\
\text { with state of } \\
\text { health }\end{array}$ & 0,495 & 0,429 & 0,165 & 0,258 & 0,388 & & 0,220 & 0,124 & 0,340 & 0,109 & 0,404 \\
\hline $\mathbf{p}$ & 0,001 & 0,006 & 0,308 & 0,109 & 0,013 & & 0,174 & 0,445 & 0,032 & 0,502 & 0,010 \\
\hline
\end{tabular}

Conclusion. The data will set the ground for forthcoming follow up studies in 6 and 12 months after the hip fracture.

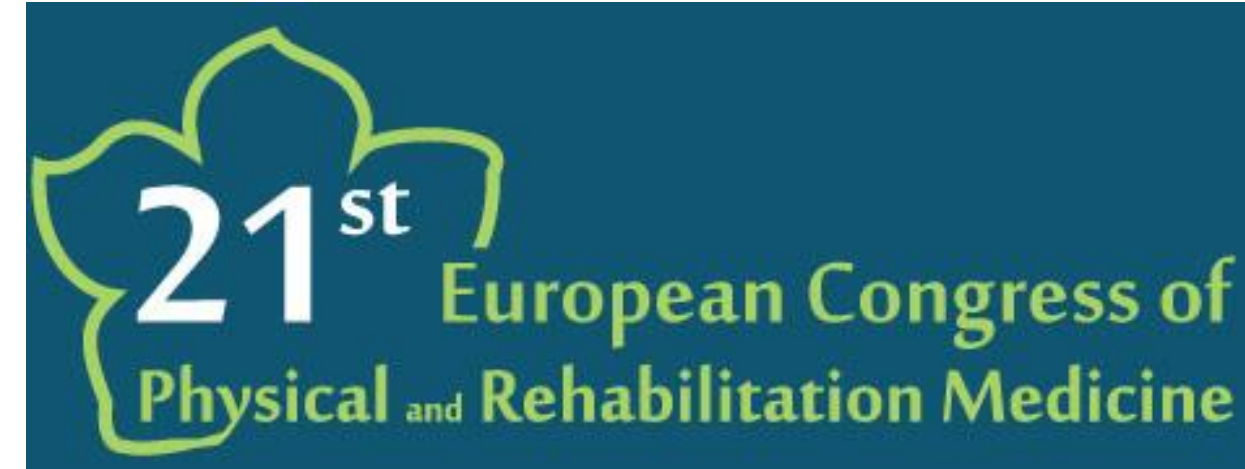

